28 Defense Manpower and Data Center (DMDC). Status of Forces Survey of Reserve Component Members. DMDC, 2004 (http://www.dod.gov/pubs/foi/ personnel/07-F-2315_SOFS-Reserves20071203.pdf).

29 King DW, King LA, Taft C, Hammond C, Stone ER. Directionality of the association between social support and posttraumatic stress disorder: a longitudinal investigation. J Appl Soc Psychol 2006; 36: 2980-92.

30 Elo A-L, Leppanen A. Can a single item measure of stress be valid? Work Stress 2000; 14: 192-3.
31 Wanous JP, Reichers AE, Hudy MJ. Overall job satisfaction: how good are single-item measures? J Appl Psychol 1997; 82: 247-52.

32 Kendler, KS, Gardner, CO, Prescott, CA. Toward a comprehensive developmental model of major depression in men. Am J Psychiatry 2006; 163: $115-24$.

33 Brewin, CR, Andrews, B, Valentin, JD. Meta-analysis of risk factors for posttraumatic stress disorder in trauma-exposed adults. J Consult Clin Psychol 68: 748-66.

\section{psychiatry in the Old Testament}

\section{Morbid jealousy may have been recognised in the Old Testament}

\section{George Stein}

The Book of Numbers describes a horrific punishment called the sotah for women who were unfaithful to their husbands. The priest puts some curses in writing, dishevels the woman's hair and makes her drink the 'water of bitterness' (a mixture of dust with holy water), which gives her severe abdominal pain. As a consequence, her womb discharges, her uterus drops and she may be rendered infertile. Women who have not been unfaithful will retain their fertility despite this procedure. For further details of the sotah the reader is referred to Num. 5:16-28.

But how is the unfaithful wife doomed to the punishment of the sotah to be identified? There appear to be three separate categories of infidelity: (1) undiscovered but true infidelity; (2) discovered and true infidelity; (3) suspicion of infidelity where the wife has not been unfaithful.

Num. 5:12 'If any man's wife goes astray and is unfaithful to him, 13 if a man has had intercourse with her but it is hidden from her husband, so that she is undetected, though she has defiled herself and there is no witness against her since she was not caught in the act; 14 if a spirit of jealousy comes on him and he is jealous of his wife who has herself defiled herself; 15 or if a spirit of jealousy comes on him and he is jealous of his wife, though she has not defiled herself then the man shall bring his wife to the priest'.

In this passage, v. 15 is the critical verse suggestive of morbid jealousy and it is of great interest that the more recent translations of the Bible use the word suspicion instead of 'spirit of jealousy' in this passage.

Thus the Moffatt Bible (translated in 1941) has: 'if he has a fit of suspicion [emphasis added], suspecting his wife even although she may not have defiled herself, he must take his wife before the priest ....'

The New International Version (translated 1973) has: 'or if he is jealous or suspects her [emphasis added] even though she is not impure - then he is to take his wife to the priest...'

The Jerusalem Bible (translated from Hebrew into French and then into English, 1973) has: 'or again if this spirit of suspicion comes over him [emphasis added] and makes him suspicious of his wife even when she is innocent - the man will bring his wife before the priest'.

Such a description is remarkably close to the concept of morbid jealousy. The ancient Israelites clearly recognised that the suspicion of jealousy was the main problem and that even if such suspicions were false, suspicious men needed urgent mollification, as described later in the chapter. From the Moffatt Bible:

5:29 'Such is the ritual in cases of suspicion, when a woman has gone astray and made herself unclean while under her husband's authority, 30 or when a spirit of suspicion has come over a man and made him suspicious of his wife. When a husband brings such a woman before Yahweh, the priest will apply this ritual in full. 31 The husband will be guiltless, but the woman shall bear the consequences of her guilt.'

The ancient Israelites seem to have recognised that men afflicted by such suspicions (whether founded or unfounded) could not be ignored. Morbid jealousy is currently classified as one of the delusional disorders and is recognised as a dangerous condition, sometimes even associated with homicide. In the ancient world, it was the woman who bore the brunt of the punishment, even when she had done nothing wrong and only formed the focus of the man's delusional jealousy. Today there has been a small advance in that the women are no longer blamed for this condition, but in a difficult case a marital separation is still sometimes the only available treatment option. 